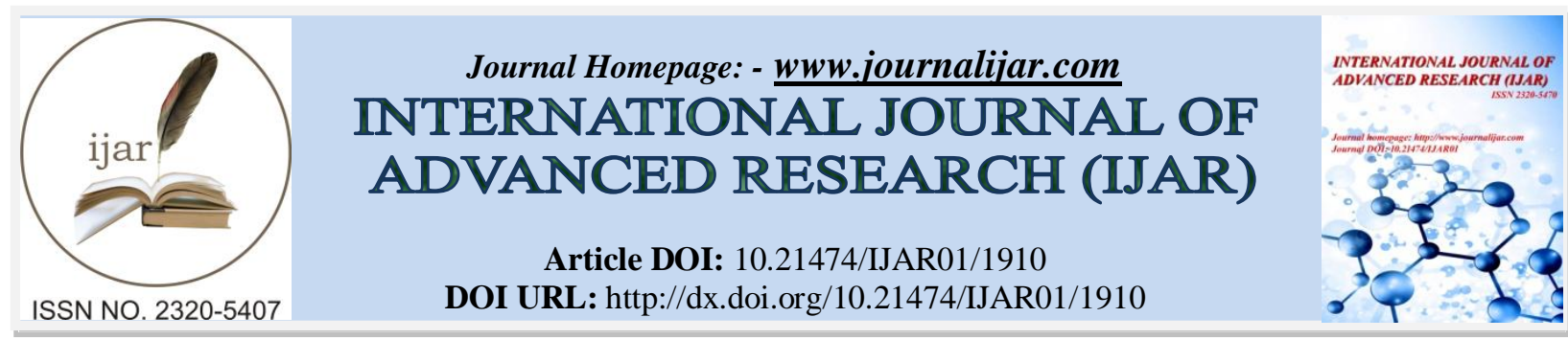

RESEARCH ARTICLE

\title{
MOLECULAR STUDY ON BETA-THALASSEMIA CHILDREN PATIENTS IN A PORTION OF THE ALGERIAN POPULATION (NORTHEAST ALGERIA)
}

\section{Belhadi. Kamilia' ${ }^{1}$, Yahia Mouloud ${ }^{1}$, Gribaa Moez $^{2}$, Bendaoud Fadhila ${ }^{3}$, Ben Charfeddine Ilhem ${ }^{2}$, Manoubi.Wiem ${ }^{2}$ and Zidani Abla ${ }^{1}$.}

1. Laboratory of Biotechnology of Bioactive Molecules and Cell Pathophysiology, University of Batna 2. Algeria.

2. Laboratory of Human Cytogenetics, Molecular Genetics and Reproductive Biology, Farhat Hached University Hospital, Sousse, Tunisia.

3. Department of Pediatrics, University Hospital of Batna, Algeria

\section{Manuscript Info}

Manuscript History

Received: 12 August 2016

Final Accepted: 16 September 2016

Published: October 2016

Key words:-

Beta-thalassemia, Mutation, $H B B$ Gene, Algeria.

\section{Abstract}

Objective:- This study was planned to determine the frequency of $B-$ thalassemia mutations in Batna region (northeast Algeria).

Materials and Methods:- 19 blood samples of clinically thalassemic children patients were collected from department of pediatrics, university hospital of Batna. We carried out the molecular genetics of beta globin gene by the method of minisequencing using Snapshot TM kit (Applied Biosystems) in search of the four most common $H B B$ genetic variants including three $\beta$-thalassemia mutations: codon 39(C>T) (HBB: c. 118C > T), IVSI-110(G>A) (HBB: c.93-21G>A) and IVSI-1-2(T>G) (HBB: c.92+2T>G), as well as the hemoglobin $S$ variant (HBB: c. 20A>T) and we used direct DNA sequencing to detect the rare mutations of beta- globin gene.

Results:- We have revealed the presence of four different $\beta$-globin gene mutations responsible for $\beta$-Thalassemia in region of Batna. According to our results; the nonsense mutation at codon $39(\mathrm{C}>\mathrm{T})$, is the most frequent mutation type in our province the same as other geographical regions of Algeria, followed by codon 54(-T), this molecular lesion was detected in a second Algerian family; the proband was homozygote, and the first association of $\mathrm{Hb}$ Knossos: codon $27(\mathrm{G}>\mathrm{T})$ allele with codon $39(\mathrm{C}>\mathrm{T})$ in Algerian population. Here we report also association of codon $39(\mathrm{C}>\mathrm{T})$ with IVS-I-110 (G>A).

Conclusion:- our preliminary results show the heterogeneity of the beta-thalassemia mutations in the region of Batna.

Copy Right, IJAR, 2016,. All rights reserved.

\section{Introduction:-}

Beta-thalassemia is a recessive monogenic disorder encountered worldwide with a higher prevalence among Mediterranean, Middle Eastern and Indian populations (Weatherall DJ, 1991). The disease is due to mutation in beta globin locus for which more than 200 alleles have been reported (Weatherall DJ and Clegg JB, 2002). Numerous disorders of the $\beta$-globin chain of hemoglobin lead to different disease phenotypes.(Thein SL ,2008; Weatherall DJ and Clegg JB ., 2001) Of these, $\beta$-thalassemia is a subset of the hemoglobinopathies characterized by a hereditary 
anemia with a wide phenotypic spectrum that can have significant morbidity and mortality.(Weatherall DJ and Clegg JB .,2001; Rund D and Rachmilewitz E .,2005). The $\beta$-thalassemia exhibit a range of severities, each corresponding to an absence or reduction of $\beta$-globin protein synthesis. These $\beta$-thalassemia phenotypes are related to the myriad mutations that affect the $\beta$-globin gene $(H B B)$ on chromosome $11 \mathrm{p} 15.5$, and different populations have their own mutation spectrum (Thein SL., 2002). In Algeria, the frequency of $\beta$-thalassemia gene is 3\% (Belhani M., 2009); these diseases are a real public health problem often compounded by rate inbreeding of the population (30$32 \%$ ) (Bellis $\mathrm{G}$ et al, 2001). Previous investigations have disclosed a high molecular heterogeneity of $\beta$-thalassemia (Bennani C, et al., 1993; Bennani C, et al., 1994). This study aims to describe the mutation spectrum from a sample of $\beta$-thalassemia patients and from $\beta$-thalassemia carriers. In addition the present study was performed to assess the usefulness of the minisequencing technique as an alternative strategy for genetic diagnosis of $H B B$ gene disorders as a screening technique for the detection of unknown $\beta$-globin gene mutations.

\section{Materials and Methods:-}

This study was realized in $\beta$-thalassemia homozygous children and from $\beta$-thalassemia carriers (age brackets 4 to 16 year old of male and female sex). These subjects are from the region of Batna, cared in the pediatric ward of the University Hospital Batna. Venous blood samples of $2.5 \mathrm{ml}$ volume were drawn from the study subjects and were collected in EDTA anticoagulant containers. Blood withdrawals were performed a few minutes before the regular blood transfusion for patients homozygous whereas heterozygous children the sampling is performed during family investigations.

\section{DNA Extraction:-}

The molecular analysis of the $H B B$ gene was carried out after taking informed written consent from all the parents of the minors. Genomic DNA was extracted from peripheral blood leukocytes using the FlexiGene-DNA Kit (Cat \# 51206; Qiagen Inc., Valencia, CA, USA) and stored at $4{ }^{\circ} \mathrm{C}$.

\section{Minisequencing reaction of $\mathrm{HBB}$ gene:-}

The minisequencing assay was developed for the detection of the four most common $H B B$ genetic variants including three $\beta$-thalassemia mutations: codon 39(C>T) (HBB: c.118C>T), IVSI-110(G>A) (HBB: c.93-21G>A) and IVSI-1$2(\mathrm{~T}>\mathrm{G})(H B B:$ c $.92+2 \mathrm{~T}>\mathrm{G})$, as well as the hemoglobin $\mathrm{S}$ variant $(H B B: \mathrm{c} .20 \mathrm{~A}>\mathrm{T})$. To detect these four mutations, an allele specific PCR was performed, followed by highly multiplexed minisequencing reaction. The specific primer sequences of the $H B B$ gene and PCR conditions are available upon request. Polymerase chain reaction products were purified using QIAquick PCR Purification by Kit (Qiagen Inc.). Purified fragments were used as template in a primer extension reaction containing the mutation-specific primer cocktail (see Table I).

For the extension reaction, we used the SNaPshot Multiplex Kit (Applied Biosystems, Foster City, CA, USA), following manufacturer's instructions. After extension, the samples were treated with shrimp alkaline phosphatase according to the manufacturer protocol.

Multiplex minisequencing products were resolved by automated capillary electrophoresis ABI PRISM 310 Genetic Analyzer (Applied Biosystems). Briefly, $12 \mathrm{ml}$ of HiDi TM formamide and 0, $5 \mathrm{ml}$ size GeneScan 120 LIZcalibrator (Applied Biosystems) were added to $1 \mathrm{ml}$ of multiplex minisequencing product. The mixture was denatured at $95{ }^{\circ} \mathrm{C}$ for $3 \mathrm{~min}$. next transferred to ice for $2 \mathrm{~min}$. and loaded on an ABI PRISM ® 310 Genetic Analyzer capillary.

Table I:- Primers for multiplex minisequencing analysis.

\begin{tabular}{|l|l|}
\hline Investigated mutations & $\begin{array}{l}\text { Minisequencing primers } \\
\text { (sequences in 5' }>\text { 3' direction) }\end{array}$ \\
\hline HbS $(H B B: c .20 \mathrm{~A}>\mathrm{T})$ & $\mathrm{T}(45)$ ATG GTG CAC CTG ACT CCT G \\
\hline IVS-I-2 $(\mathrm{T}>\mathrm{G})(H B B: \mathrm{c} .92+2 \mathrm{~T}>\mathrm{G})$ & $\mathrm{T}(55)$ GTG AGG CCC TGG GCA GG \\
\hline IVS-I-110 $(\mathrm{G}>\mathrm{A})(H B B: \mathrm{c} .93-21 \mathrm{G}>\mathrm{A})$ & $\mathrm{T}(65)$ ACT GAC TCT CTC TGC CTA TT \\
\hline Codon 39 $(\mathrm{C}>\mathrm{T})(H B B: \mathrm{c} .118 \mathrm{C}>\mathrm{T})$ & $\mathrm{T}(75)$ GTG GTC TAC CCT TGG ACC \\
\hline
\end{tabular}

* The variants are described using Human Genome Variation Society nomenclature. 


\section{G C I T}

a. Wenescan 3.7 -

SNAPSHOT

E) File Edit Project Sample Settings View Windows Help

$+9$

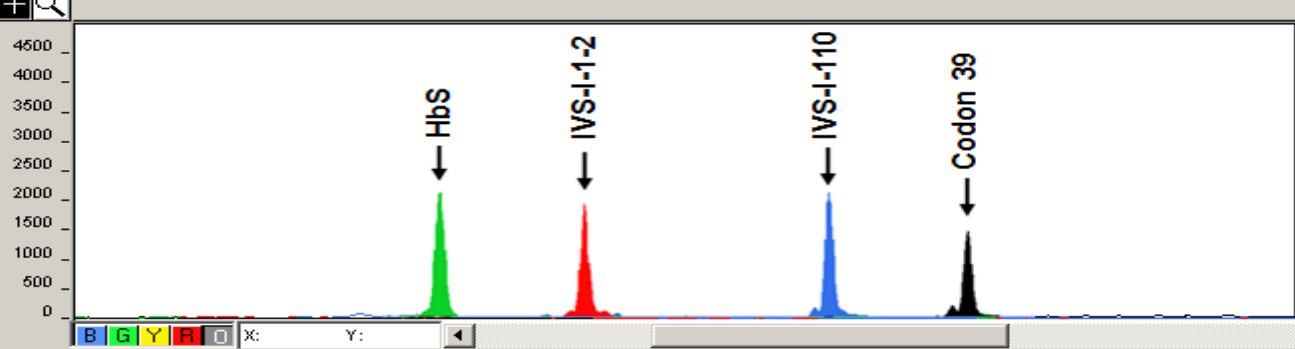

|B|G|Y|R|OX:

beneScan 3.7-
b. TNAPSHOT

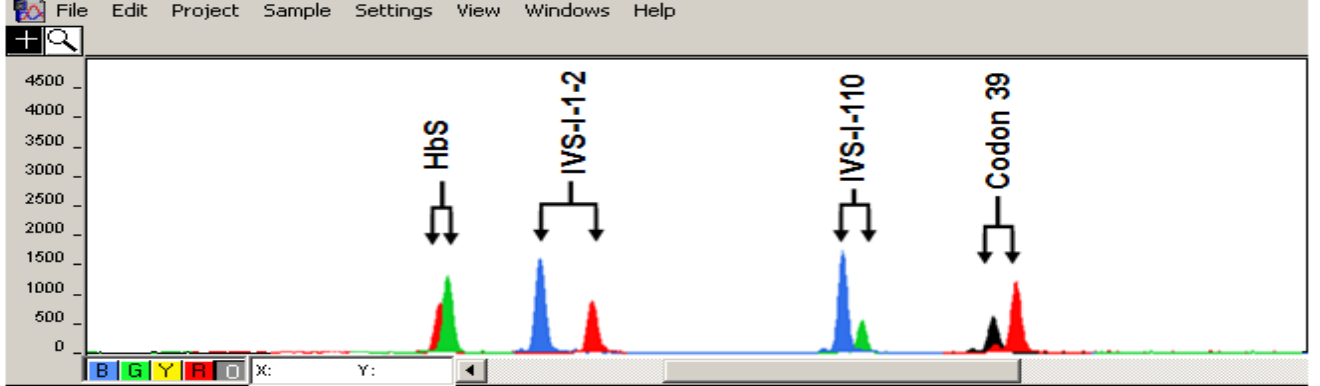

C.

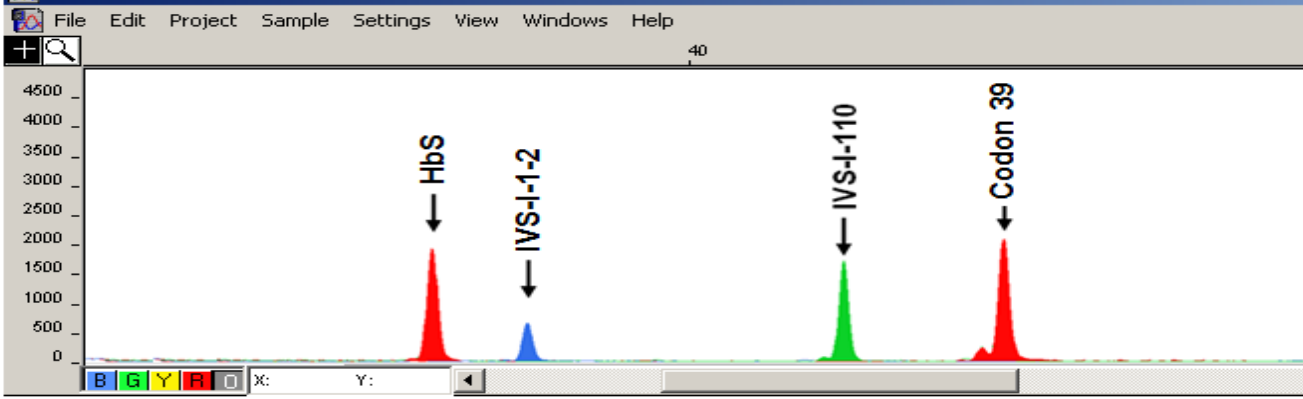

Figure 1:- GeneScan analysis of the multiplex minisequencing reaction. Electropherograms: (a) shows the analysis results of a $H B B$ wild-type sample; (b) illustrates the pattern of peaks for all mutant positions in the heterozygous state; (c) illustrates the pattern of peaks for all mutant positions in the homozygous state.

\section{Direct DNA sequencing:-}

If the minisequencing technique presents a snapshot normal, we use the direct DNA sequencing. The $\beta$-globin gene was amplified using couples of primers: $\boldsymbol{H B B} \mathbf{F}$ : 5'- CTG ACA CAA CTG TGT TCA CT-3'and $\boldsymbol{H B} \boldsymbol{B}$ R: 5'- TTC ACC TTA GGG TTG CCC -3'.

The $\beta$ - thalassemia mutation was identified by automated sequence analysis performed on an ABI Prism 310 Genetic Analyzer (Applied Biosystems, Foster City, CA, USA) using the fluorescent dideoxy-termination method (Big Dye-Terminator Cycle Sequencing Kit, Applied Biosystems, Foster City, CA, USA).

\section{Results:-}

Here we apply the minisequencing technique as an alternative strategy for genetic diagnosis of $H B B$ gene disorders in children with $\beta$-thalassemia, provided by the pediatrics department, Hospital Batna (Northeast of Algeria). We chose this method as it allows quick search of the 4 most common and frequent mutations of the $H B B$ gene. The GeneScan electropherograms of our subject's samples after multiplex minisequencing primers are shown in figures 2, 3, 4 and 5 and the results of direct DNA sequencing are shown in figures 6 and 7. 
Table II shows the results of molecular diagnosis for the 38 chromosomes from 9 individuals with beta-thalassemia trait and 10 children with beta-thalassemia major analyzed with 4 different beta-thalassemia mutations. This study confirms the observations that the frequency of several mutations varies from one ethnic group to another. The four different $\beta$-thalassemia mutations have been identified in this study, were codon $39(\mathrm{C}>\mathrm{T})$ the most frequent $\beta$ thalassemia mutations. In addition, two genetic variants without disease association, the polymorphisms codon 39 $(\mathrm{C}>\mathrm{T})$ and IVS-I-110 (G>A), a first association of Hb Knossos: $H B B$ : c.82 G>T with $H B B$ : c.118 C>T mutation causes thalassemia homozygous in the Algerian population, was found in one subject. Codon 54(-T) mutation was found in one subject who was homozygous for this molecular lesion.

Table II:- Spectrum of beta-thalassemia mutations in northeast Algeria (Batna).

\begin{tabular}{|c|c|c|c|c|c|}
\hline $\begin{array}{c}\text { HBB mutation } \\
\text { name or variant }\end{array}$ & Phenotype & $\begin{array}{c}\text { Localization } \\
\text { at } \boldsymbol{H B B}\end{array}$ & $\begin{array}{c}\text { Genomic variation } \\
\text { (HGVS) }\end{array}$ & $\mathbf{N}^{\circ}$.of Alleles & $\%$ \\
\hline Codon 39 $(\mathbf{C}>\mathbf{T})$ & $\beta 0$ & Exon 2 & c. $118 \mathrm{C}>\mathrm{T}$ & 32 & 84,21 \\
\hline IVS-I-110 $(\mathbf{G}>\mathbf{A})$ & $\beta+$ & Intron 1 & c. $93-21 \mathrm{G}>\mathrm{A}$ & 3 & 7,89 \\
\hline $\begin{array}{c}\text { Codon 27 }(\mathbf{G}>\mathbf{T}) \\
\text { Hb Knossos }\end{array}$ & $\beta+$ & Exon 1 & c. $82 \mathrm{G}>\mathrm{T}$ & 1 & 2,63 \\
\hline Codon 54(-T) & $\beta 0$ & Exon 1 & c. 165 delT & 2 & 5,26 \\
\hline
\end{tabular}

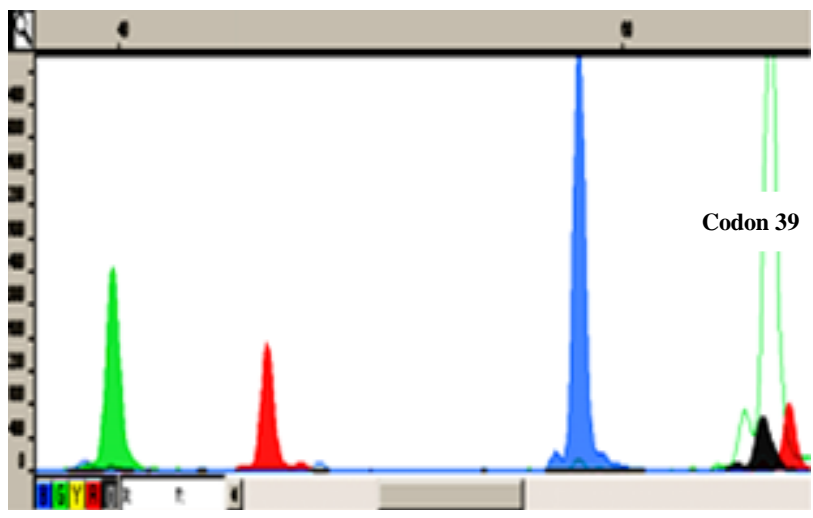

Figure 2:- Electropherogram shows a peak for codon $39(\mathrm{C}>\mathrm{T})$ mutation in the heterozygous state

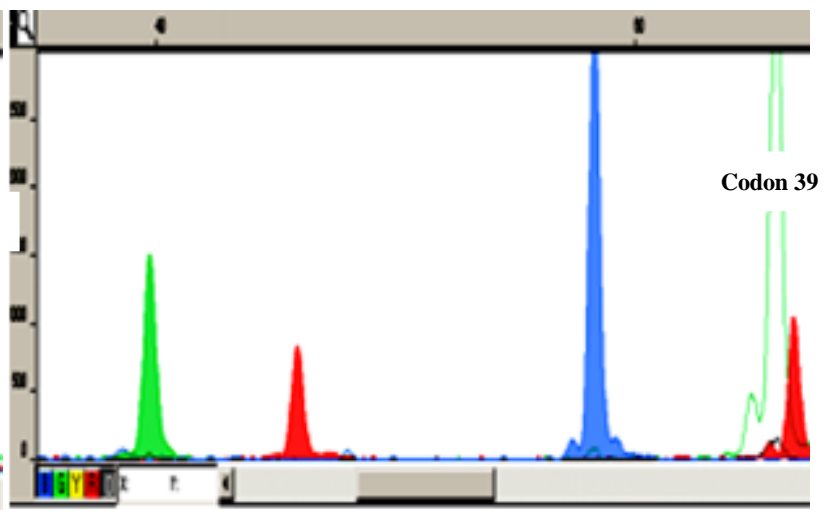

Figure 3:- Electropherogram shows a peak for codon $39(\mathrm{C}>\mathrm{T})$ mutation in the homozygous state.

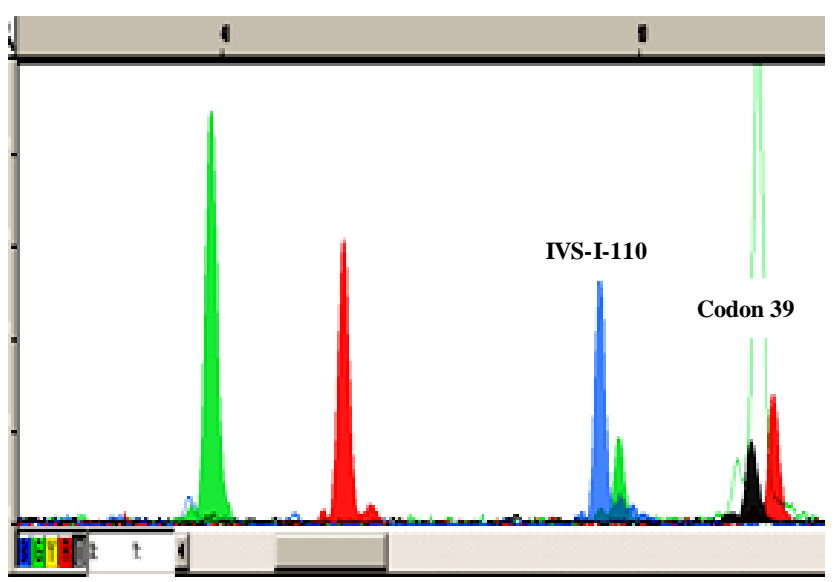

Figure 4:- Electropherogram shows a peak for codon $39(\mathrm{C}>\mathrm{T})$ mutation and IVS-I-110 $(\mathrm{G}>\mathrm{A})$ in the heterozygous composite state.

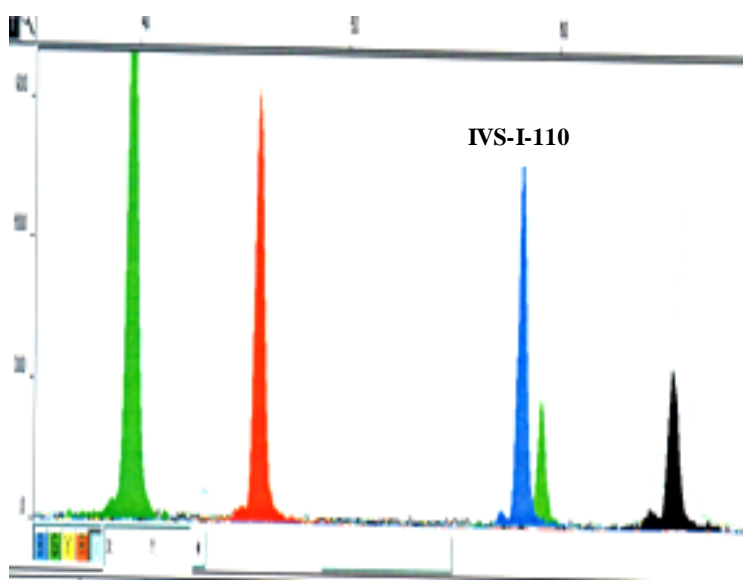

Figure 5:- Electropherogram shows a peak for IVS-I-110 (G>A) in the heterozygous state. 


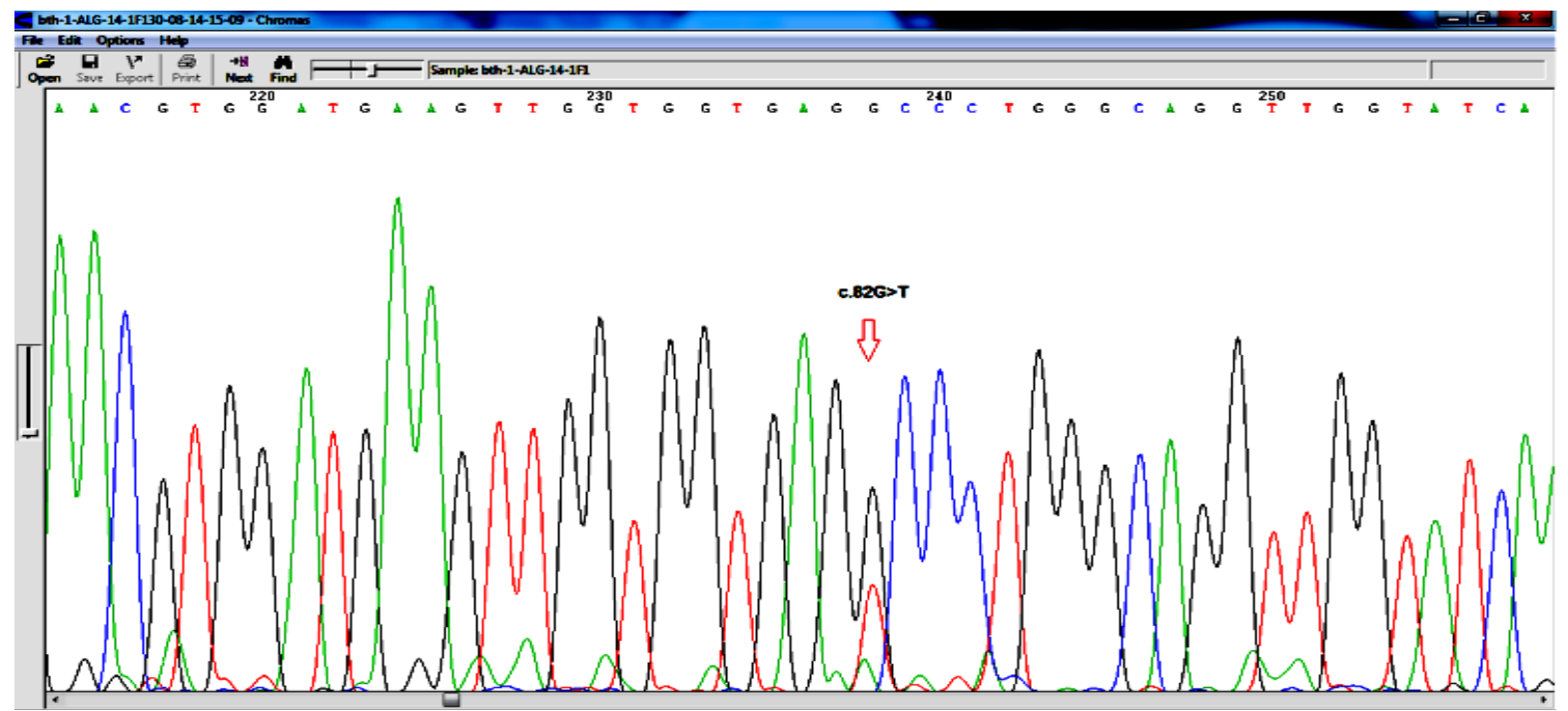

Figure 6:-Part of electropherogram obtained by sequencing the genomic DNA from the beta-thalassemic patient shows the presence of codon $27(\mathrm{G}>\mathrm{T})$ mutation (Hb Knossos).

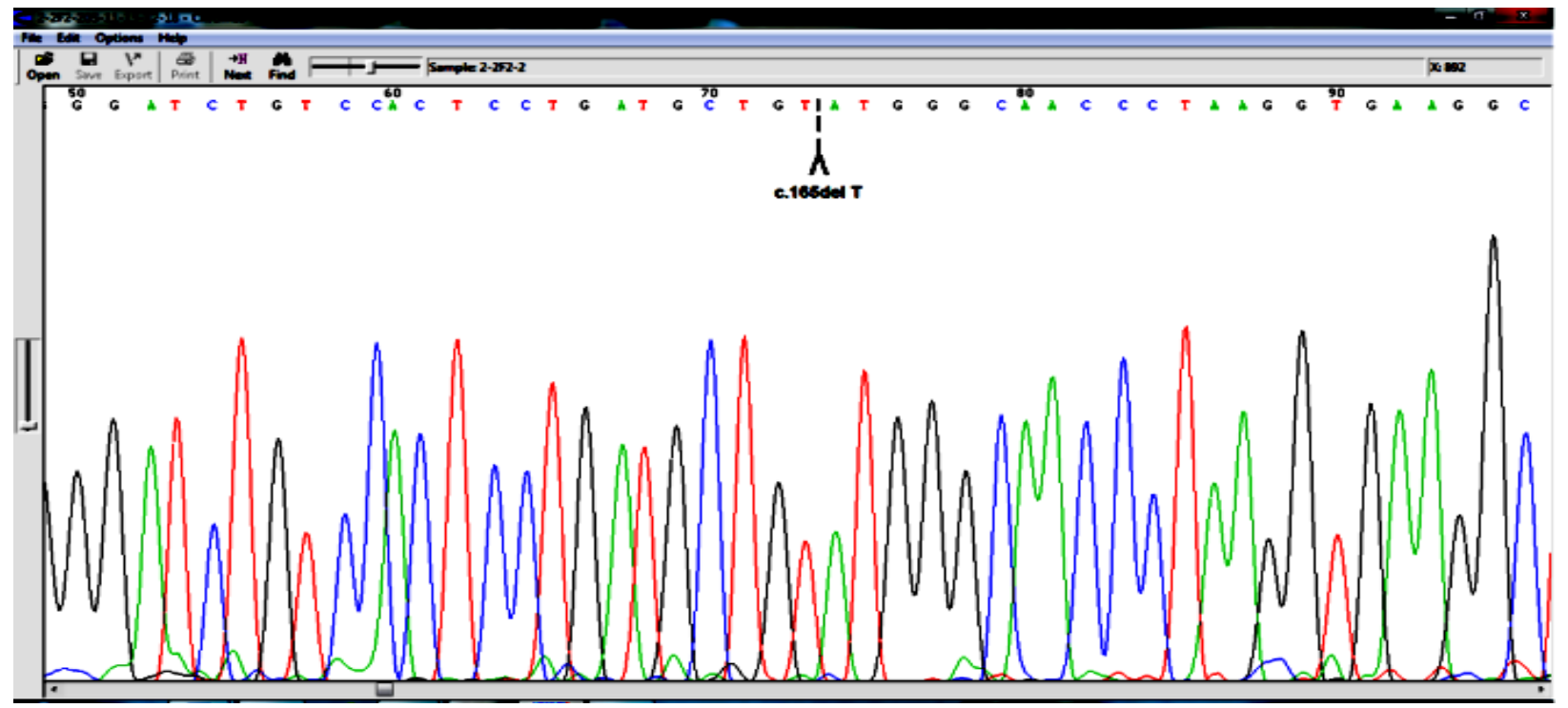

Figure 7:- Part electropherogram obtained by sequencing the genomic DNA from the homozygous beta-thalassemia patient shows the presence of c.165delT mutation.

\section{Discussion:-}

This is the first study investigating the molecular level basic of $\beta$-thalassemia in the region of Batna (Northeast Algeria). We conducted the identification and characterization of the molecular basis of $\beta$-thalassemia among children born in Batna region.

The $\beta$-thalassemia in Algeria, are by their frequency and severity of a health problem, mainly in transfusion support (Addour NB, 2008). According (Lemsaddek W et al., 2004) the prevalence of $\beta$-thalassemia allele in North Africa would increase from west to east Mediterranean countries (Morocco 0, 94\%, 1, 4\% of Algeria, Tunisia 3\% and Egypt 4, 5\%). (Barragan E et al., 2006, Tadmouri A et al., 2001). 
The great heterogeneity of molecular defects at the origin of $\beta$-thalassemia in Algeria, the number of $\beta$ - thalassemia mutations in Algeria is 25 mutations (Addour NB, 2008). On the other hand, the Algerian population is characterized by four dominant mutations, which represent over $80 \%$ of $\beta$-thalassemia alleles. These are the mutation nonsense codon $39 \mathrm{C} \rightarrow \mathrm{T}$; IVS-I-110 substitution $\mathrm{G} \rightarrow \mathrm{A}$; framshift the codon $6(-\mathrm{A})$ and mutation IVS-I$1 \mathrm{G} \rightarrow \mathrm{A}(16)$.

The nonsense mutation codon39 (C>T) is widespread in Algeria with a frequency 25, $94 \%$ (Addour NB, 2008), 27,6\% (Bennani C, Bouhass R Perrin- Pécontal P et al., 1994) and is more common in the west and decreases in center to be predominant in the East (Bouhass R et al., 1993).

The IVS-I-110 was discovered in 1981 (Spritz RA, Jagadeeswaran P, Choudary PV et al., 1981; Westaway D and Williamson R.,1981) and is caused by the replacement of a guanine by adenine in the consensus sequence, located in the first intron of the $\beta$-globin gene 19 nucleotides away from the site of splicing AG. (Orkin SH et al., 1982). The IVS-I-110 mutation found in Turkey (Perrin Pet al., 1998), represents $40 \%$ beta thalassemia alleles; it is predominant in central Algeria and located in a low frequency in the west (16\%) (Bennani C et al., 1994). His consistent distribution with the extent of the Ottoman Empire between the 16th and 19th century. In Tunisia, it is (21\%) (22 Fattoum S et al., 2004) and Egypt (26\%) (Jiffri EH et al., 2010). It is rare in Morocco (3.2\%) (Lemsaddek $\mathrm{W}$ et al., 2004).For Codon 54(-T) mutation: this is the second Algerian family which presents this mutation; the proband is homozygote also in a swedish family. The deletion of $\mathrm{T}$ from codon 54 result in framshift with a nonsense codon at codon 60 (TGA) and premature termination of translation (Landin B A, 1996).In this study, we detect a rare hemoglobin variant caused by a mutation in beta-globin gene, $H B B$ : c.82G>T (Hb Knossos), which produces the classical phenotype of intermedia beta--thalassemia in association with $H B B$ : c. $118 \mathrm{C}>\mathrm{T})$ mutation causes thalassemia homozygous in an Algerian children patient ( Fessas PH et al .,1982; Baklouti F et al ., 1986). Hb Knossos in the heterozygous state has been recently recognized as the underlying abnormality in atypical betathalassemia trait. (Fessas Ph et al., 1982; Arous N, et al., 1982). First identified in a family from Crete,Hb Knossos was discovered soon afterwards in two families from northeast Algeria and in a family from the French West Indies.(Rouabhi F et al ., 1983; Morl L et al .,1984).

\section{Conclusion:-}

In this study, we used the minisequencing assay as a rapid screening procedure to identify four most common $H B B$ genetic variants including three beta-thalassemia mutations and direct DNA sequencing to detect the rare mutations of beta- globin gene. Our data show the complexity of the beta-thalassemia mutations in our area due to the historical aspects and geographical location of region of Batna. This study confirms the heterogeneity of the betathalassemia mutations in Algerian population. Four different $\beta$-thalassemia mutations have been identified in the Batna population. Codon $39(\mathrm{C}>\mathrm{T})$ is the most frequent mutation type in our province; followed by codon 54(-T) and the first association of $\mathrm{Hb}$ Knossos: codon $27(\mathrm{G}>\mathrm{T})$ with codon $39(\mathrm{C}>\mathrm{T})$ in Algerian population. Here we report also association of codon $39(\mathrm{C}>\mathrm{T})$ with IVS-I-110 (G>A). Molecular genetic testing will be increasingly important in the future because it is anticipated that the advances in the understanding of the molecular basis of the disease may lead to specific pharmacologic therapies in the future.

\section{Acknowledgments:-}

We wish to express our appreciation for the cooperation and generosity of all contributed families

\section{Conflict of Interest:-}

The authors of this paper have no conflicts of interest, including specific financial interests, relationships, and/or affiliations relevant to the subject matter or materials included. 


\section{References:-}

1. Weatherall DJ. (1991): The thalassemias. In: Williams JW, (ed) Haematology, 6th edn. McGraw Hill, New York.

2. Weatherall DJ, Clegg JB. (2001): The thalassemia syndromes. Blackwell Science, Oxford.

3. Thein SL. (2008): Genetic modifiers of the betahaemoglobinopathies. Br J Haematol. ; 141:357-366.

4. Weatherall DJ, Clegg JB. (2001): The Thalassemia Syndromes. 4th ed.Oxford, England: Blackwell Science.

5. Rund D, Rachmilewitz E.(2005). Beta-thalassemia. N Engl J Med.; 353:1135-1146.

6. Thein SL. (2002): Beta-thalassemia prototype of a single gene disorder with multiple phenotypes. Int J Hematol.; 76(suppl 2):96-104.

7. Belhani M. (2009): Epidemiology of homozygous $\beta$-thalassemia in Algeria. Review. Algerian hematology. Spt: $\mathrm{n}^{\circ} .1, \mathrm{p}: 22$.

8. Bellis G, C Valentin, Glavce C Popescu I Ciovica C, F Vladareanu, Gerard N, R Krishnamoorthy, De Braekeleer M. (2001): Genetic population of thalassemia in Sicily and Algeria - data compared to Romania. Antropo; $1-5$ from http:// www.didac.ehu.es/antropo.

9. Bennani C, Tamouza R, Rouabhi F, et al. (1993): The spectrum of $\beta$-thalassemia in Algeria: Possible origins of the molecular heterogeneity and a tentative diagnostic strategy. Br J Haematol.84 (2):335-337.

10. Bennani C, Bouhass R, Perrin-Pecontal P, et al. (1994): Anthropological approach to the heterogeneity of BThalassemia mutations in Northern Africa. Hum Biol. 1994;66 (3):369-38.

11. Addour NB. (2008): Molecular characterization of $\beta$-thalassemia in the population Algeria: the impact of mutations on the clinical expression. Doctoral thesis; USTHB, Algiers.

12. Lemsaddek W, i Picanc Seuanes F, P Nogueira, Mahmal L, S Benchekroun, Khattab M, L Osorio. (2004): The $\beta$-Thalassemia Mutation / Haplotype Distribution in the Moroccan population. Hemoglobin. Flight. 28, $\mathrm{n}^{\circ}$. 1 , pp. 25-37.

13. Barragan E, P Bolufer, Maria LP, F Prieto, Miguel. A. S. (2006): Molecular detection of Spanish $\delta \beta$-thalassemia associated with $\beta$-thalassemia during prenatal approbation diagnosis. Clinica Chimica Acta; 368 195-198.

14. Tadmouri A, N Basak Ghazi O. B-thalassemia in Turkey. (2001): Review of the clinical, epidemiological, molecular, and evolutionary aspects. Hemoglobin; 25 (2), 227-239.

15. Bennani C, Bouhass R Perrin- Pécontal P, R Tamouza, Malou M, J Elion, Trabuchet G, C Beldjord, Benabadji million Labie D. (1994):Anthropological apprroach to theheterogeneity of a thalassemia mutations in northern Africa. Hum Biol; 66, 3: 369-382.

16. Bouhass R Perrin P, Trabuchet G. (1993): The spectrum of $\beta$-thalassemia mutations in Oran area of Algeria. Hemoglobin; 18, 3: 211 -219.

17. Spritz RA, Jagadeeswaran P, Choudary PV, Biro PA, Elder JT, deRiel JK, Manley JL, Gefter ML, Forget BG, Weissman SM. (1981): Base substitution in an intervening sequence of a beta+-thalassemic human globin gene. Proc Natl Acad Sci USA, 78(4):2455-9.

18. Westaway D, Williamson R. (1981): An intron nucleotide sequence variant in a cloned beta+-thalassaemia globin gene. Nucleic Acids Res, 9(8), 1777-1788.

19. Orkin SH, Kazazian HH, Antonarakis SE, Ostrer H, Goff SC, Sexton JP. (1982): Abnormal RNA processing due to the exon mutation of beta E-globin gene. Nature, 300(5894), 768-769.

20. Perrin P, Bouhassa R, Mselli L, Garguier N, Victor-Marc Nigon VM, Bennani C,Labie D, Trabuchet G; (1998). Diversity of sequence haplotypes associated with $\beta$-thalassaemia mutations in Algeria: implications for their origin. Gene 213, 169-177.

21. Bennani C, Bouhass R, Perrin- Pecontal P, Tamouza R, Malou M, Elion J, Trabuchet G, Beldjord C, Benabadji M, Labie D; (1994):Anthropological apprroach to the heterogeneity of a thalassemia mutations in northern Africa. Hum Biol; 66, 3: 369-382.

22. Fattoum S, Messaoud T, Bibi A.( 2004):Molecular Basis of $\beta$-Thalassemia in the Population of Tunisia. Hemoglobin, Vol. 28, No. 3, pp. 177-187.

23. Jiffri EH, Bogari N, Zidan KH, Teama S, Elhawary N.( 2010): Molecular updating of $\beta$-thalassemia mutation in the upper Egyptian population. Hemoglobin, 34(6):538-547.

24. Lemsaddek W, Picanc I, Seuanes F, Nogueira P, Mahmal L, Benchekroun S, Khattab M, Osorio L. (2004): The $\beta$-Thalassemia Mutation/Haplotype Distribution in the Moroccan Population. Hemoglobin. Vol. 28, No. 1, pp. $25-37$.

25. Landin B A.(1996): novel mutation in the beta-globin Berglund gene causing beta-thalassemia in a swedish family. EU J Haematol 57, 2, 182, 4.

26. Fessas PH, Loukopoulos D, Loutradi-Anagnostou A, Komis G.(1982): "Silent" $\beta$-thalassemia caused by a "silent" $\beta$-chain mutant: The pathogenesis of a syndrome of thalassemia intermedia. Br J Haematol51:577. 
27. Baklouti F, DorlCac E, Morle L, Laselve P, Peyramond D, Aubry M, Godet J, Delaunay J(1986):: Homozygous hemoglobin Knossos (a2 $\beta 2$ [B9] Ala-Ser): A new variety of $\beta+$-thalassemia intermedia associated with $\delta$ thalassemia. Blood 67:957.

28. Fessas Ph, Loukopoulos D, Loutradi-Anagnostou A, Komis G. (1982): 'Silent' $\beta$-thalassaemia caused by a 'silent' $\beta$-chain mutant: The pathogenesis of a syndrome of thalassemia intermedia. Br J Haematol 51:577.

29. Arous N, Galacteros F, Fessas Ph, Loukopoulos D, Blouquit Y, Komis G, Sellaye M, Boussiou M, Rosa J.( 1982): Structural study of hemoglobin Knossos, /327 (B9) Ala -' $5 \mathrm{cr}$. A new abnormal hemoglobin present as a silent $\beta$-thalassemia. FEBS Lett 147:247.

30. Rouabhi F, Chardin P, Boissel JP, Beghoul F, Labie D, Benabadji M: (1983): Silent $\beta$-thalassemia associated with $\mathrm{Hb}$ Knossos $\beta 27$ (B9) Ala -. 5cr in Algeria. Hemoglobin 7:555, 19.

31. MorlL, Baklouti F, Baudonnet C, Godet J, Delaunay J. (1984): The association of hemoglobin Knossos and hemoglobin Lepore in an Algerian patient. Hemoglobin 8:229. 